\title{
Ectopic expression of miRNA172 in tomato (Solanum lycopersicum) reveals novel function in fruit development through regulation of an AP2 transcription factor
}

Mi-Young Chung ${ }^{1}$, Ujjal Kumar Nath², Julia Vrebalov${ }^{3}$, Nigel Gapper ${ }^{3}$, Je Min Lee, Do-Jin Lee ${ }^{4}$, Chang Kil Kim ${ }^{4^{*}}$ and James Giovannoni $i^{3,5^{*}}$

\begin{abstract}
Background: MicroRNAs (miRNAs) are short non-coding RNAs that can influence gene expression via diverse mechanisms. Tomato is a fruit widely consumed for its flavor, culinary attributes, and high nutritional quality. Tomato fruit are climacteric and fleshy, and their ripening is regulated by endogenous and exogenous signals operating through a coordinated genetic network. Much research has been conducted on mechanisms of tomato fruit ripening, but the roles of miRNA-regulated repression/expression of specific regulatory genes are not well documented.

Results: In this study, we demonstrate that miR172 specifically targets four SIAP2 transcription factor genes in tomato. Among them, SIAP2a was repressed by the overexpression of SImiR172, manifesting in altered flower morphology, development and accelerated ripening. miR172 over-expression lines specifically repressed SIAP2a, enhancing ethylene biosynthesis, fruit color and additional ripening characteristics. Most previously described ripening-regulatory genes, including RIN-MADS, NR, TAGL 1 and LeHB-1 were not influenced by miR172 while CNR showed altered expression.

Conclusions: Tomato fruit ripening is directly influenced by miR172 targeting of the APETALA2 transcription factor, SIAP2a, with minimal influence over additional known ripening-regulatory genes. miR172a-guided SIAP2a expression provides insight into another layer of genetic control of ripening and a target for modifying the quality and nutritional value of tomato and possibly other fleshy fruit crops.
\end{abstract}

Keywords: Tomato, SIAP2a, miR172, Fruit ripening, Ethylene

\footnotetext{
*Correspondence: ckkim@knu.ac.kr; jjg33@cornell.edu

${ }^{4}$ Department of Horticulture, Kyungpook National University, Daegu, Korea

${ }^{3}$ Boyce Thompson Institute for Plant Research, Cornell University, Ithaca, New

York, USA

Full list of author information is available at the end of the article
}

(c) The Author(s). 2020 Open Access This article is licensed under a Creative Commons Attribution 4.0 International License, which permits use, sharing, adaptation, distribution and reproduction in any medium or format, as long as you give appropriate credit to the original author(s) and the source, provide a link to the Creative Commons licence, and indicate if changes were made. The images or other third party material in this article are included in the article's Creative Commons licence, unless indicated otherwise in a credit line to the material. If material is not included in the article's Creative Commons licence and your intended use is not permitted by statutory regulation or exceeds the permitted use, you will need to obtain permission directly from the copyright holder. To view a copy of this licence, visit http://creativecommons.org/licenses/by/4.0/ The Creative Commons Public Domain Dedication waiver (http://creativecommons.org/publicdomain/zero/1.0/) applies to the data made available in this article, unless otherwise stated in a credit line to the data. 


\section{Background}

MicroRNAs (miRNAs) are short, non-coding RNAs of approximately 18-24 nucleotides in length. Eukaryotic miRNAs derive from endogenously-processed RNA transcripts as long, primary transcripts (pri-miRNA), which are then transcribed by a ribonuclease III-like nuclease and Dicer-like (DCL) proteins. Among the four DCL proteins in Arabidopsis thaliana, DCL1 participates in the production of miRNAs with the aid of other accessory proteins $[1,2]$. The long pri-miRNAs adopt imperfect single-stranded hairpin structures that contain the miRNA in one arm of the stem [3]. This folding is essential for their processing by RNAse III, which cleaves them into pre-miRNAs. The miRNAs are broadly grouped as intronic (transcribed from the intron of the host transcript) and intergenic (transcribed independently by DNA-dependent RNA polymerase II) [4].

miRNAs function as developmentally regulated repressors of gene expression either by mediating the cleavage of complementary mRNA or by suppressing translation [5-10]. Mature miRNAs can be incorporated into the RNA-induced silencing complex (RISC) or other RISC-like complexes involved in the negative regulation of target genes [6,11-15]. During rapid changes of developmental phases [16], one strand of the miRNA duplex is abandoned by unraveling or cleavage [17], and the other strand is retained in the RISC for recognition of target mRNA. Transcriptional silencing by targeted cleavage has been found to predominate in plants, facilitating straight-forward predictions of likely target genes using computational approaches based on available genome sequences [18-21].

In plants, miRNAs are involved in environmental interactions, numerous developmental processes (for example, the control of meristem identity, cell proliferation, developmental timing, and pattern formation events), and serve as key regulators of organ development [15, 22]. At the posttranscriptional level, plant miRNAs have been shown to regulate metabolic processes via binding cis- and transregulatory sites to repress protein translation [21, 23-25]. The role of miRNAs in regulating gene expression has been extensively investigated regarding growth and development, signal transduction, hormone signaling, innate immunity, and response to diverse biotic and abiotic stresses in Arabidopsis and other plant species [15, 26-28].

Fleshy fruit ripening is the summation of numerous biochemical and physiological processes coordinated by developmental, hormonal, and environmental cues influencing pigmentation, texture, aroma, flavor, and nutritional composition [29]. Tomato (Solanum lycopersicum) is the most studied model for fleshy fruit because of its simple diploid genetics and small genome size $(900$ $\mathrm{Mb}$ [ [30], short life cycle, efficient transformation, distinct phenotypes in ripening, dense genetic maps, expanding genomic resources, and the availability of its high-quality genome sequence [31-33].

Positional cloning of well-characterized tomato mutants, such as rin (ripening-inhibitor), $\mathrm{Gr}$ (green-ripe), $\mathrm{Nr}$ (neverripe), gf (green flesh), and Cnr (colorless non-ripening), provided insights into fundamental aspects of molecular regulation in fruit ripening, most notably, the ripeningregulatory pathway influencing ethylene biosynthesis and signaling [29, 34-37]. Additional regulators have been identified by transcriptome analysis, and their roles confirmed through either repression, overexpression, or CRISPR/Cas9 gene editing (NAC1, FUL1, FUL2, MADS1, TAGL1, and SlAP2a) [38-42], or interaction with other regulators (LeHB-1 and TDR4) [42-44]. Potential regulatory networks of miRNAs and the RIN-MADS gene during tomato fruit development and ripening have been elucidated through deep sequencing and expression profiling of the identified miRNAs in the wild-type (WT) tomato [45]. miRNAs have additionally been associated with DNA methylation and promoter activity [46].

The miR172 family has been implicated in the regulation of a subfamily of APETALA2 (AP2) transcription factor genes [47, 48]. In Arabidopsis, miR172 influences floral organ identity through AP2 [49], and flowering time through down-regulation of TOE1 (TARGET OF EAT1) and TOE2 (TARGET OF EAT2) [50]. In maize, miR172 has been found to block the binding site of the AP2 family gene glossy15 (gl15) and plays a central role in maintaining juvenility [51]. Although miR156 regulates the juvenile-to-adult phase transition in Arabidopsis and delays flowering, as evident from the overexpression of miR156, the opposite phenotype was found in overexpressed miR172 lines [52-54].

Genome sequences contribute to miRNA discovery. Yin et al. [55] detected 21 conserved miRNAs and their corresponding target genes in tomato, including five $\mathrm{pu}-$ tative AP2 family targets of miR172, by adopting a computational homology search approach. To further address the role of miRNAs in fruit biology, we characterized the functional roles of the AP2 family genes and their miRNA regulation. Specifically, we analyzed the role of miR172 in floral determination and fruit ripening in tomato and show that miR172 overexpression mimics SLAP2a RNAi repression phenotypes. We further demonstrated a regulatory role of miR172 operating through SlAP2a in fleshy fruit development distinct from activities previously identified in the dry fruit of Arabidopsis.

\section{Results}

\section{Functional analysis of miR172 in tomato}

Accumulation of miR172 in tomato was assessed by RNA gel-blot analysis. Figure 1a and additional file 1 show that miR172 accumulated predominantly in leaves 


\begin{tabular}{|l} 
(A) \\
5s RNA
\end{tabular}

and flowers and declined during fruit development. The miR172 transcript accumulated abundantly during the early stages of flower bud, carpel, and stamen development (Fig. 1b and additional file 1).

To analyze the function of miR172 in tomato, $403 \mathrm{bp}$ of genomic sequence spanning miR172 (pre-miR172; Tomato Bacterial Artificial Chromosome (BAC)-end seq MboI (SL_MboI0036L22_T7_268826)/Tomato WGS Chromosomes SL2.40ch11) (solgenomics.net), termed SlmiR172a (NCBI accession 102,464,333), was amplified by PCR from the indicated BAC clone. This sequence was ligated downstream of the cauliflower mosaic virus ( $C a M V$ ) $35 \mathrm{~S}$ promoter in vector $\mathrm{pBI} 121$, transformed into
Agrobacterium tumefaciens strain LBA4404 and transformed the WT tomato cv. Ailsa Craig. Twenty-five kanamycin (kan) resistant independent transformed lines $\left(\mathrm{T}_{0}\right)$ were confirmed by PCR of the kan gene. Three of these overexpression (OE) lines were selected based on phenotype and copy number (two strong phenotypes lines 13 and 16, and one weak single-copy phenotype line 26) in the $\mathrm{T}_{2}$ generation and used for subsequent studies. The miR172 transcript was abundant in the three homozygous transgenic lines compared with WT controls in both flowers and 3 days post-breaker stage (early ripening) fruit, with higher abundance in flowers than B3 fruit (Fig. 2 and additional file 1).

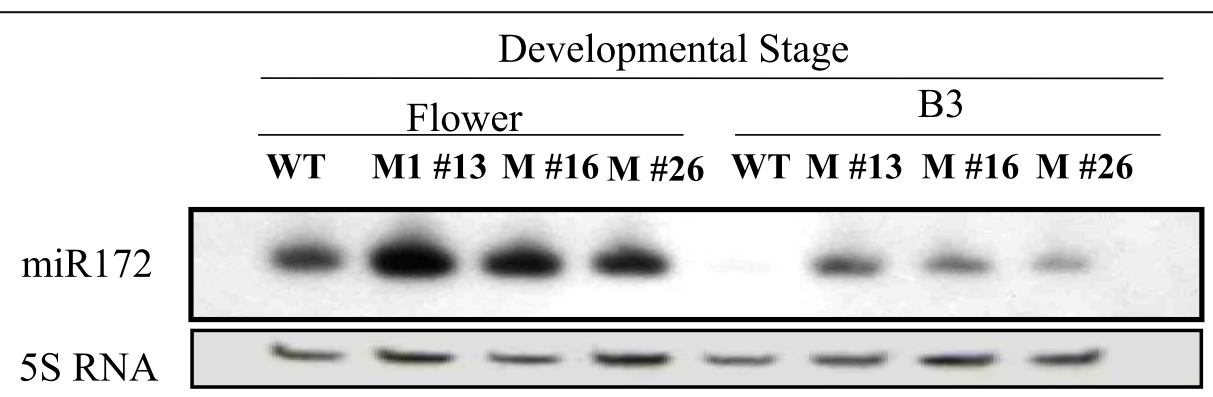

Fig. 2 RNA gel blot analysis of miR172 levels in wild-type (WT) and mir172 OE lines (M \#13, M \#16, M \#26) at B3 (3 days after breaker) 


\section{Overexpression of miR172 influences flowering time and floral pattern in tomato}

miR172 is known to affect floral organ identity and flowering time via translational repression of AP2 family members in Arabidopsis [49, 50, 56]. The number of leaves produced before the first inflorescence in SlmiR172a OE lines was, on average, one leaf less than in the WT when grown in 16-h light/8-h dark photoperiod (tomato is day-neutral; Fig. 3a). The time to first flower was reduced by $4-5$ days in miR172 OE lines (Fig. 3b). In addition, overexpression of SlmiR172 resulted in enlarged sepals, narrow petals, and sepal-to-petal transformation (Fig. 4a, b).

\section{SImiR172a regulates fruit ripening through SIAP2a}

Repression of SlAP2a by miRNA in tomato affected fruit ripening, ethylene production, ripening time, carotenoid biosynthesis, and the expression of ripening-related genes $[42,57]$. SlAP2a has been shown to contain a putative SlmiR172a binding site [42]. Here, the duration of development from $1 \mathrm{~cm}$ fruit to breaker in SlmiR172a OE lines was 4-6 days earlier than in untransformed controls (Table 1), resembling the effect of SlAP2a repression. At early fruit development ( 8 days after $1 \mathrm{~cm}$ ), an enlarged calyx was apparent (Fig. 5a). No distinct differences in ripe fruit color intensity were noted between the SlmiR172a OE lines and WT (Fig. 5).

For precise characterization of pigment composition in SlmiR172a OE and WT lines, we measured carotenoid of ripe fruit using HPLC. Pericarp lycopene accumulation in SlmiR172a OE lines M \#16 and M \#26 was similar to WT, but dramatically reduced in line $\mathrm{M} \mathrm{\# 13}$ (Fig. 6). $\beta$-carotene was elevated approximately two-fold in the fruit of all three SlmiR172a OE lines relative to
WT. We also measured expression of carotenoid biosynthesis genes including DXS1 (1-deoxy-D-xylulose 5phosphate synthase), PSY1 (phytoene synthase 1), PDS (phytoene desaturase), and ZDS ( $\zeta$-carotene desaturase), which showed abundant mRNA accumulation, and only the downstream gene $C Y C-B$ (lycopene- $\beta$-cyclase) was substantially increased in SlmiR172a OE lines compared to the WT (Fig. 7 and additional file 1). CYC-B catalyzes the conversion of lycopene to $\beta$-carotene, which was significantly elevated in the ripe fruit of SlmiR172a OE lines consistent with elevated $C Y C-B$ expression.

\section{Function of miR172 in regulation of ethylene production}

Ethylene is a critical ripening hormone of climacteric fruit, including tomato. To determine the role of miR172 on fruit ethylene production, we measured ethylene evolution at five fruit development stages by gas chromatography. miR172a OE fruit ethylene increased three- to four-fold from onset of ripening compared to the WT control, and remained unchanged 7 days after breaker (Fig. 8).

We monitored mRNA abundance of ethylene biosynthesis genes, 1-AMINOCYCLOPROPANE 1CARBOXYLIC ACID SYNTHASE (ACS2), ACS4, and 1AMINOCYCLOPROPANE-1-CARBOXYLIC ACID OXIDASE (ACO1), and ethylene-responsive ( $E 4$ and $E 8$ ) genes during fruit development. All five genes were induced approximately five-fold higher in miR172a OE lines at B and B3 stages of fruit ripening as compared to WT (Fig. 9 and additional file 1). Taken together, ethylene and corresponding gene expression data indicate that miR172a influences fruit ethylene biosynthesis through repression of the SIAP2a transcription factor. miR172a OE phenocopied SIAP2a repression [42].

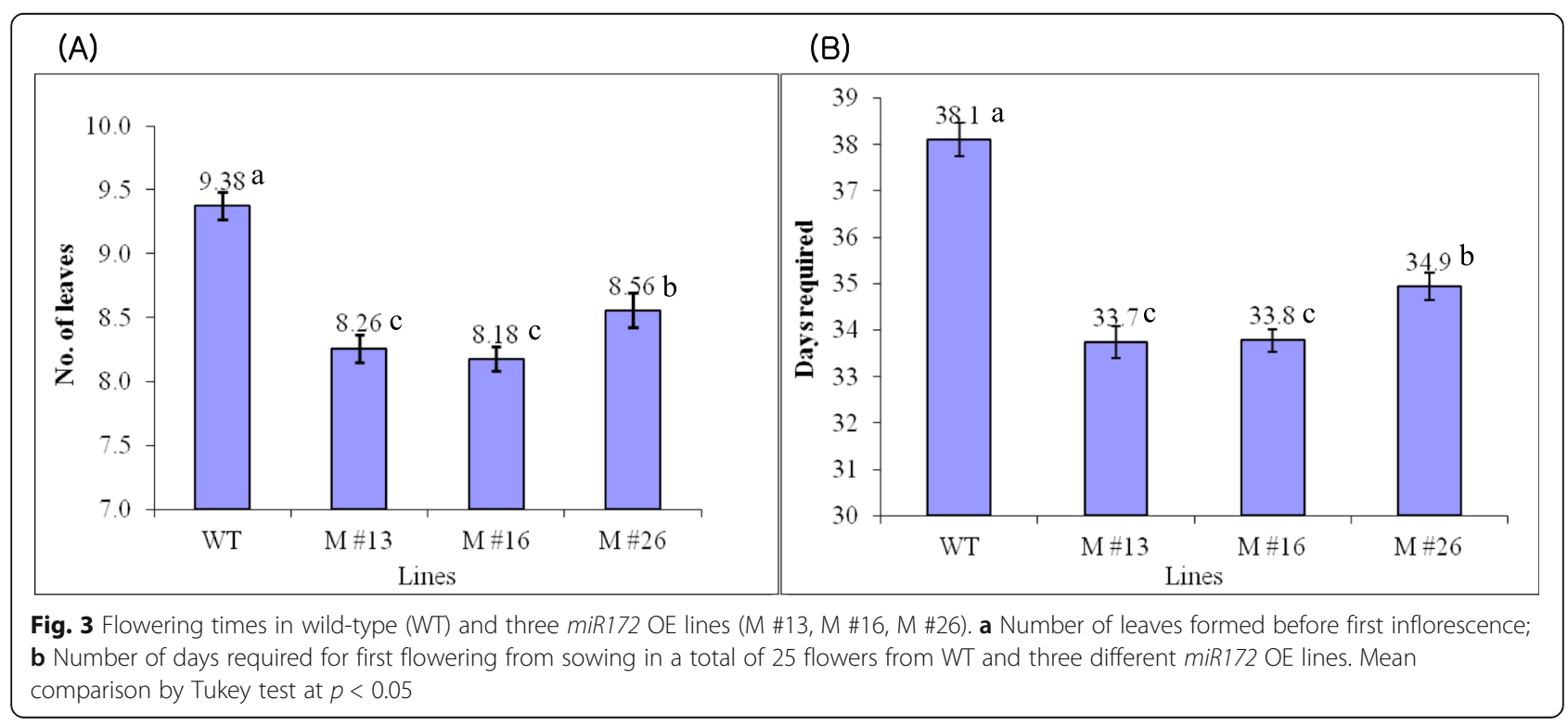



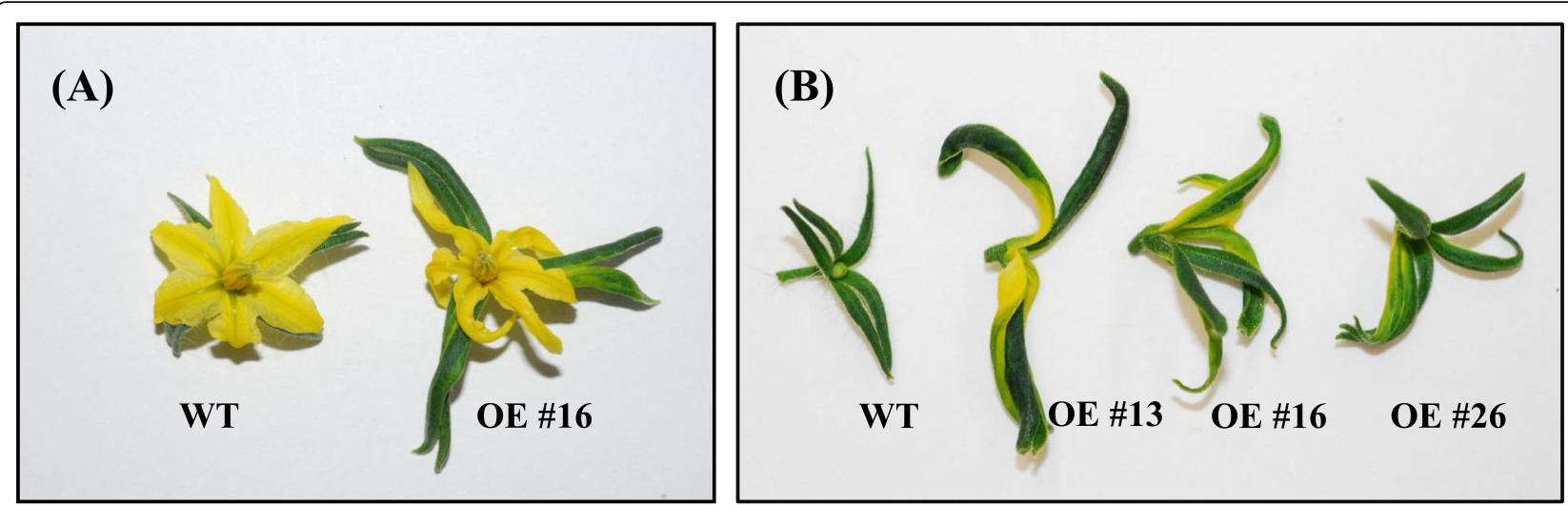

Fig. 4 Phenotypes of flowers in wild-type and miR172OE lines ( $T_{2}$ generation). Transgenic flower that overexpressed miR172 showed enlarged sepal and more curved, rippled petal compared with the wild-type; $\mathbf{b}$ Flowers with removed petals and stamen; miR172 overexpression lines showed a range of sepal-to-petal transformations depending on expression level

Identification of miR172-guided RNA cleavage and its role in miR172a OE lines

To predict miR172-guided cleavage products, we aligned miR172 and five putative target gene sequences SlAP2a, SlAP2b, SlAP2c, Target 4, and Target 5 (Supplementary data 1). We then used RNA ligase-mediated 5 '-rapid amplification of cDNA ends ( $5^{\prime}$-RACE) on five predicted targets of miR172a. Four out of five predicted targets showed specific cleavage sites that corresponded to the miRNA complementary sequence, except for SlAP2b (Fig. 10). All cleavage events occurred close to the middle of the complementary strands, identical to the cleavage site of Arabidopsis miR172. SlAP2b did not show cleavage (Fig. 10). We attempted to detect cleavage of $S I A P 2 b$ using repeated RACE-PCR with many additional 3 '-gene-specific primers to no avail though it is possible technical issues could be the cause. However, RACEPCR with a 19-bp adapter sequence and 5-bp cleavage sequence primers amplified target sequence in miR172a OE lines.

We performed RT-PCR to assess transcript abundance of predicted target genes in miR172 OE lines and WT and observed amplification of SlAP2 $a$ and $S I A P 2$ at $\mathrm{B} 3$ and $A P 2 b$ in flower of miR172a OE lines (Supplementary Fig. S1A,B and additional file 1). Meanwhile, the cleavage products of Target 4 and Target 5 genes amplified in WT and miR172a OE

Table 1 Days required for fruit maturation as measured from 1 $\mathrm{cm}$ fruit to breaker stage in wild-type and miR172 OE lines

\begin{tabular}{ll}
\hline Genotype & Days $^{\mathrm{a}}$ \\
\hline Wild-type & $28.43 \pm 0.14 \mathrm{a}$ \\
miR172 OE \#13 & $22.54 \pm 0.12 \mathrm{C}$ \\
miR172 OE \#16 & $23.18 \pm 0.17 \mathrm{C}$ \\
miR172 OE \#26 & $24.52 \pm 0.19 \mathrm{~b}$ \\
\hline
\end{tabular}

${ }^{a}$ Values represent mean \pm SE of at least 10 fruit from each line; lowercase letters $(\mathrm{a}, \mathrm{b}, \mathrm{c})$ denote significant difference by Tukey test at $p<0.05$ lines at B3. Only SlAP2a was detected by northern blot in B and B3 miR172a OE fruit (Supplementary Fig. S2 and additional file 1). Other SlAP2 (SlAP2b and $S l A P 2 c$ ) genes were not detected, consistent with SIAP2a's known role in fruit development and ripening. Accumulation of the SlAP2a transcript was reduced in miR172a OE lines compared to WT, indicating that tomato $m i R 172 a$ is involved in downregulating SlAP2 genes (SlAP2a, SlAP2b, and SlAP2c) via miRNA binding site cleavage.

\section{miR172 and ripening-related regulatory genes}

The observed role of $m i R 172 a$ in fruit ripening and floral organ identity motivated us to investigate the relationship if any between $m i R 172$ and other ripening regulatory genes, specifically, MADS-RIN (RIPENING INHIBITOR), CNR-SPB (COLORLESS NON-RIPENING), HB1 (HD-ZIP HOMEOBOX PROTEIN-1), and NOR (NON-RIPENING). During fruit ripening, only $N R$ showed expression differences between miR172 OE lines and WT (Fig. 11 and additional file 1). We additionally performed RNA gel-blot analysis of miR172 in several tissues of genotypes harboring mutations in these ripening genes (rin, nor, Cnr, and Nr; Supplementary Fig. S3 and additional file 1). Only $\mathrm{Cnr}$ showed miR172 levels that were different than WT with miR172 transcript higher in ripe $\mathrm{Cnr}$ compared to WT (Supplementary Fig. S4). This result suggests that SICNR is influenced by miR172 though this effect may be indirect and possibly mediated by SIAP $2 a$.

\section{Discussion}

miR172 is a highly conserved miRNAs in plants. miR156/157, miR170/171, and miR165/166 have also evolved as orthologs. Together these miRNAs play important and conserved roles in plant and especially floral development [15, 20, 48, 58-60]. For example, 

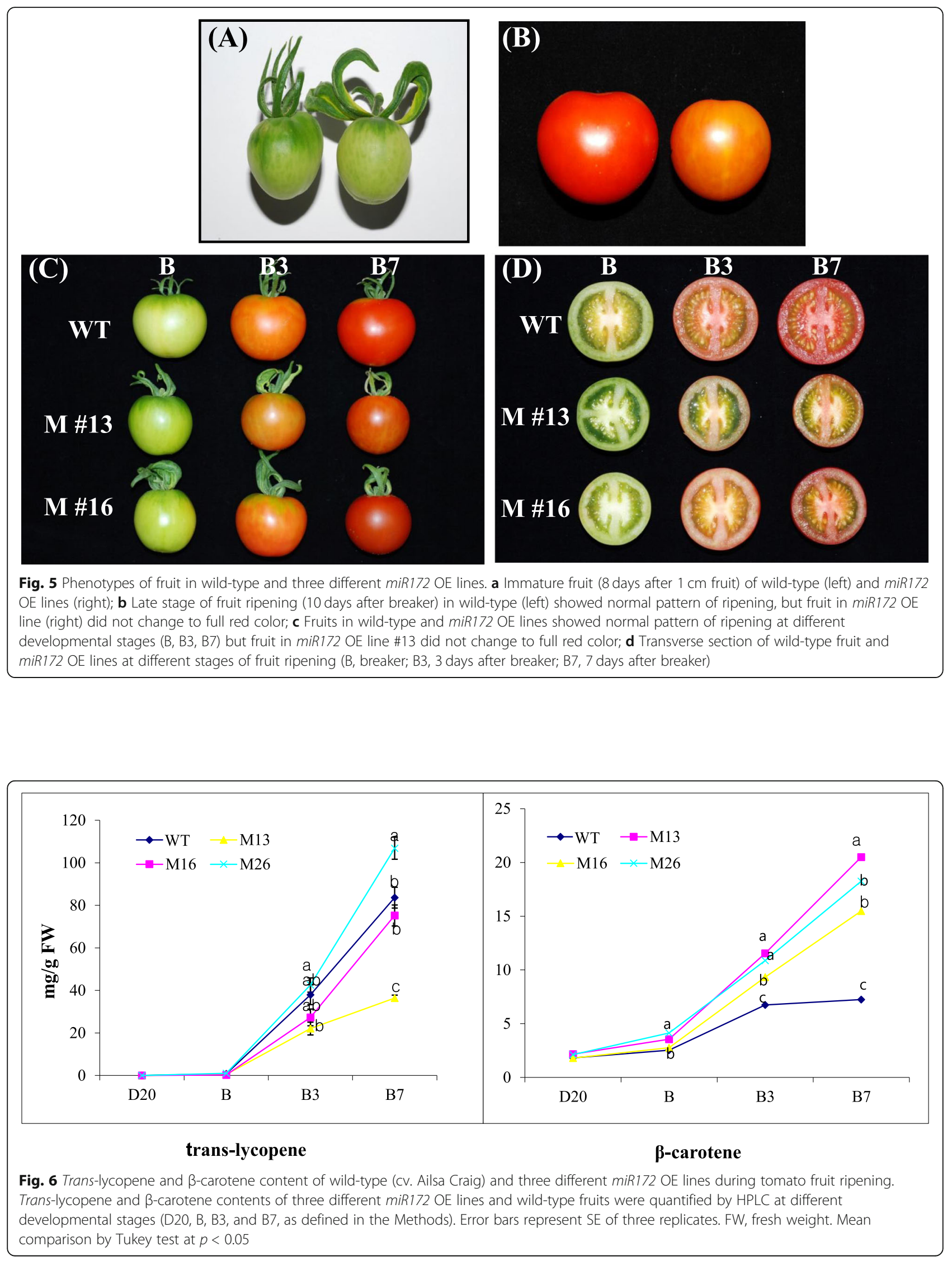
WT miR172OE \#13 MiR172OE \#16
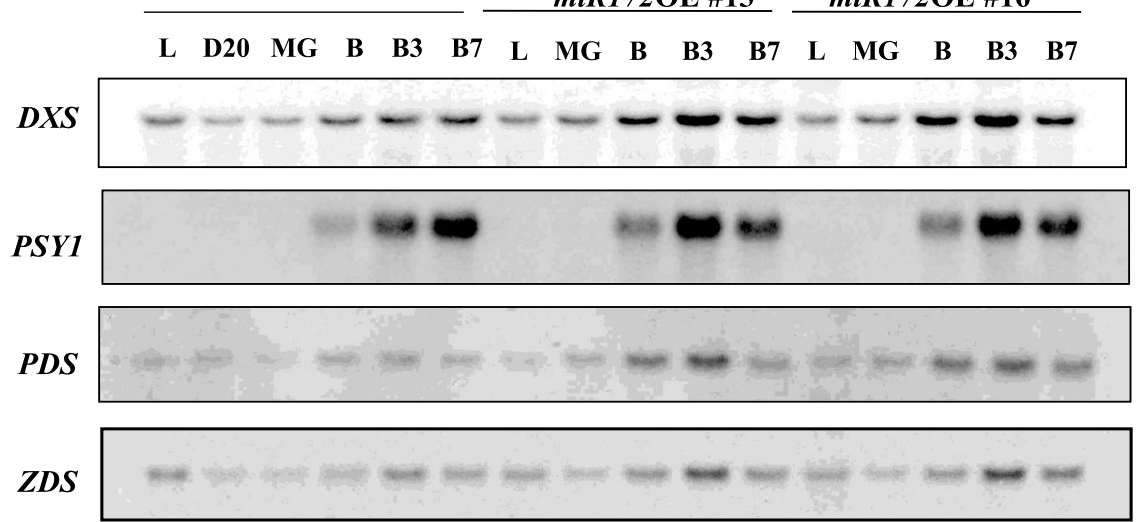

\section{CYC-B}

18S RNA

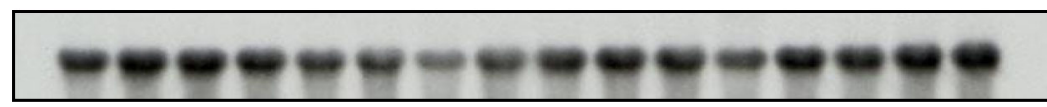

Fig. 7 Expression of genes related to carotenoid biosynthesis in wild-type (WT) and miR172 OE lines (\#13 and \#16). Total RNA was extracted from fruit at various developmental stages (L, D20, B, B3, and B7, as defined in the Methods). Twenty micrograms of RNA was loaded and hybridized with DXS, PSY1, PDS, ZDS, and CYC-B gene-specific probes. The filter-strip rehybridized with tomato 18S RNA probe was used as a control

miR172, miR156, and miR159 influence flowering time in A. thaliana [50, 61, 62]. Three different tomato miR172 sequences were identified via sRNA cloning from leaf, flower bud, and fruit [61, 62], with the loop structure precursors denoted miR172a, miR172b, and miR172c [58, 63]. Although the tomato genome sequence was published in 2012 [64], investigations of miRNAs in tomato are limited. In this study, we annotated the pre-miRNA sequence (pre-miR172; Tomato BAC-end seq_MboI (SL_MboI0036L22_T7_268826)/Tomato WGS Chromosomes SL2.40ch11) as SlmiR172a, which is similar to the predicted sequence reported by Itaya et al. [61], and overexpressed it under the $35 \mathrm{~S}$ promoter. The transgenic plants affected not only flowering in Arabidopsis but also fruit ripening presumably through interaction with its likely target gene, SlAP2a [43].

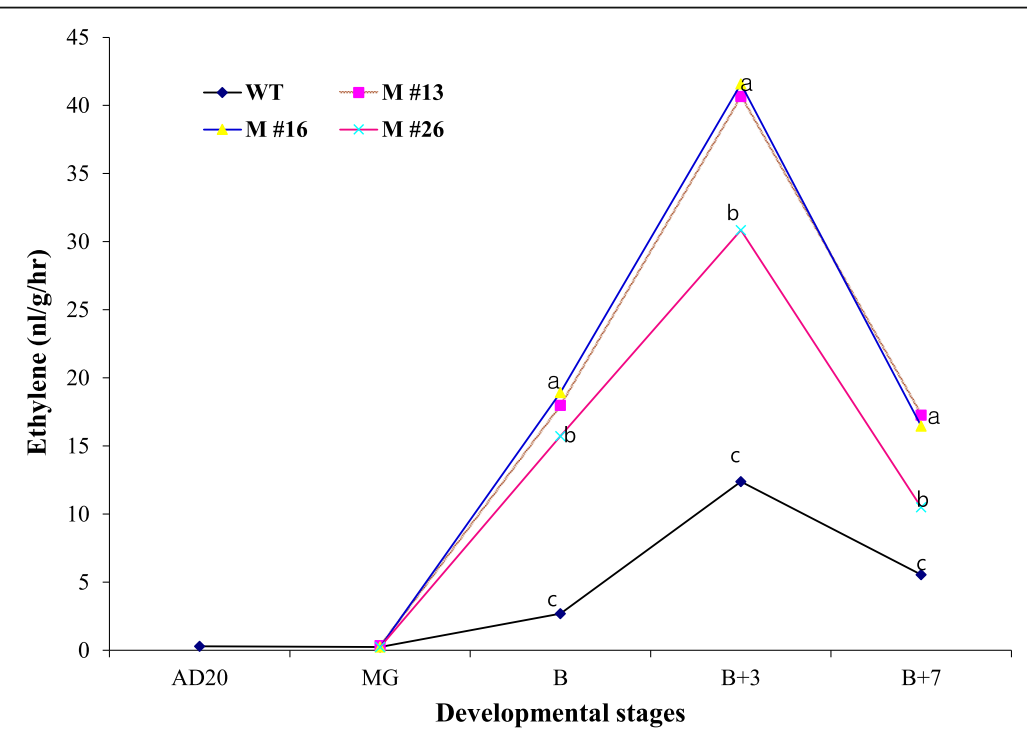

Fig. 8 Production of ethylene in the fruits of wild-type (WT) and three different miR172 OE lines (\#13, \#16, and \#26) at different developmental stages: D20 (20 days after $1 \mathrm{~cm}$ fruit), MG (24 days after $1 \mathrm{~cm}$ fruit), B (breaker), B3 (3 days after breaker), B7 (7 days after breaker). Values represent mean of at least 15 individual fruit. Mean comparison by Tukey test at $p<0.05$ 


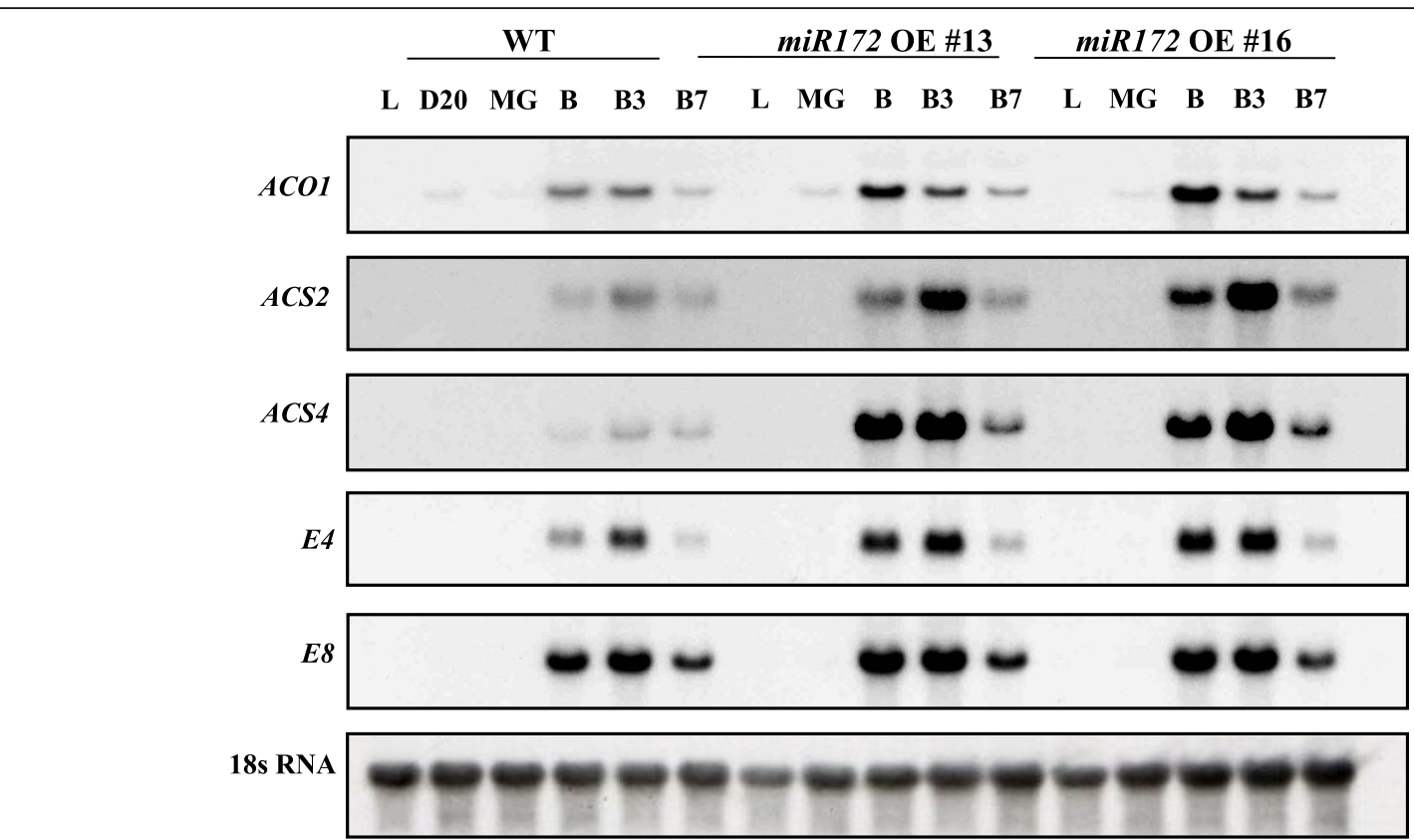

Fig. 9 Gene expression of ethylene biosynthesis-related genes ACO1, ACS2, and ACS4, as well as the level of E4 and E8 in wild-type and miR172 OE lines (\#13 and \#16). Total RNA was extracted from fruit at various developmental stages (D20, B, B3, and B7), as well as from leaf. Twenty micrograms of RNA was used in northern blot with P32-labeled CDNA probes. The filter-stripped and rehybridized tomato 185 RNA probe was used as a control

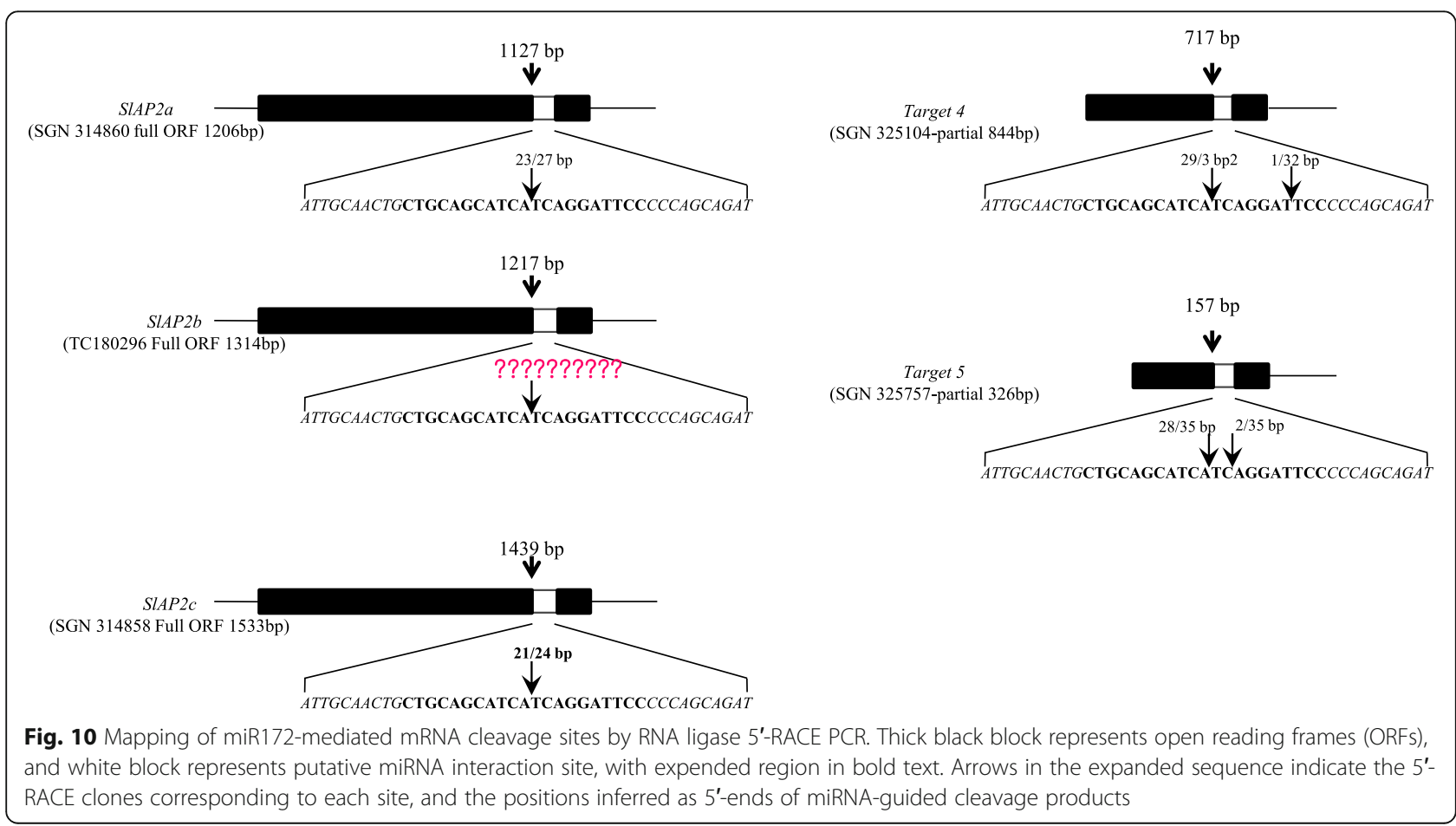




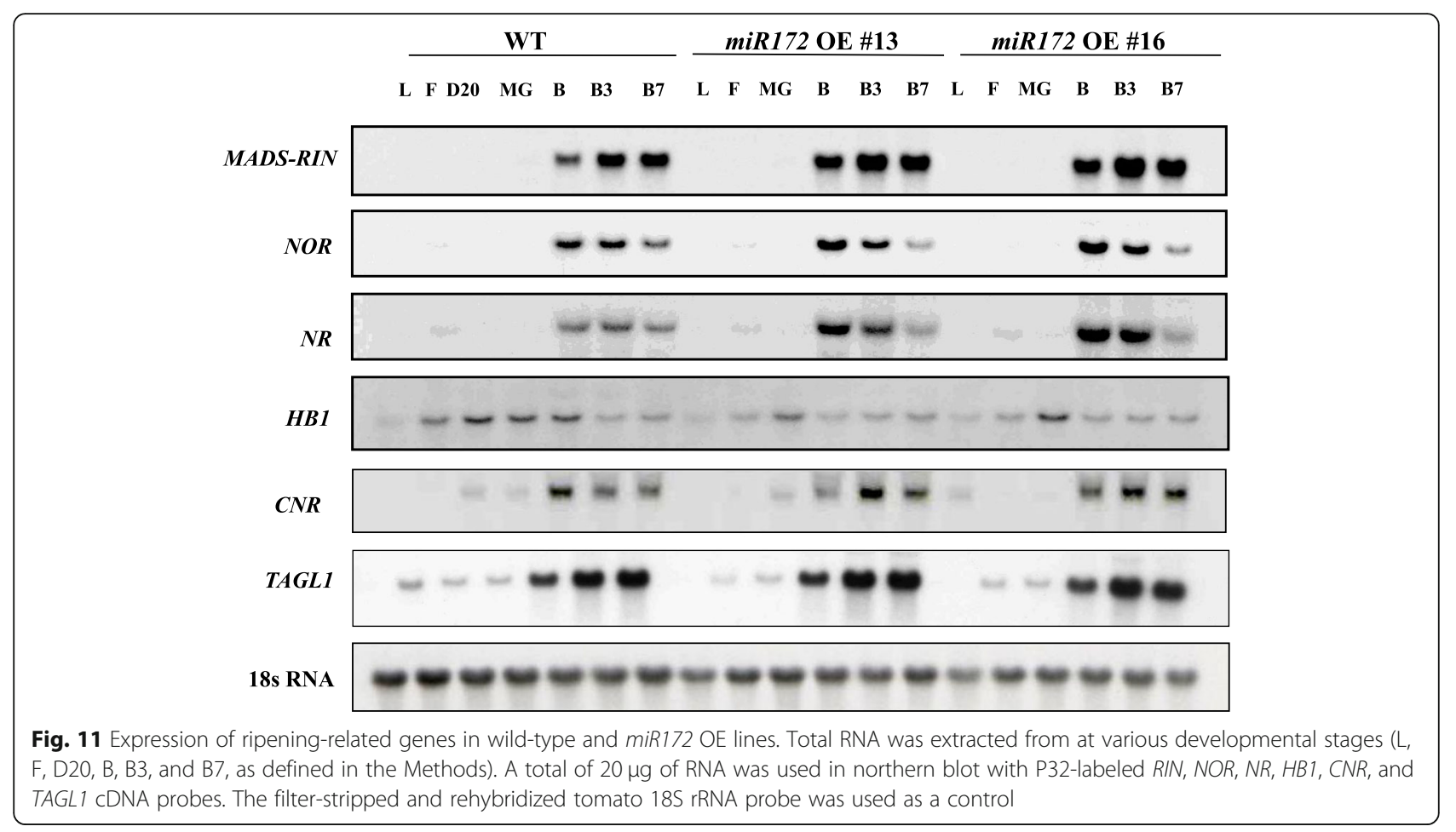

\section{Floral homeotic transformation and early flowering in miR172 OE lines}

The miR172 transcript was abundant at the early stages of tomato flower bud, carpel, and stamen development (Fig. 1b), similar to C-group floral homeotic genes [50, $65,66]$. This temporal expression pattern of miR172 is similar to Arabidopsis where accumulation gradually increases shortly after germination until flowering [50, 67]. Expression of tomato miR172 is consistent with function in floral and fruit development, presumably as in floral organ identity in Arabidopsis and Antirrhinum via regulation of genes acting in the $\mathrm{ABC}$ floral development model $[66,68]$. In the $A B C$ model, transcription factor genes comprise three classes of floral homeotic genes. Here we demonstrate that overexpression of SlmiR172a in tomato affected floral pattern as manifested by enlarged sepals and sepal-to-petal transformation (Fig. 4). Additional phenotypes correlated with the transcriptional abundance of SlmiR172a (Fig. 1a, b and additional file 1). Interestingly, tomato sepal-to-petal transformation differed from phenotypes observed with Arabidopsis miR172 overexpression, in which accumulation of $35 \mathrm{~S}$ driven miR172 expression resulted in a phenotype similar to Arabidopsis ap 2 mutants including abnormal and late-flowering $[49,69]$. Furthermore, overexpression of miR172-resistant AP2 resulted in elevated AP2 protein and presented a defective floral pattern resembling the ag (agamous) mutant, including loss of floral determinacy, suggesting miR172 down-regulates AP2 during floral development [49, 70]. Arabidopsis sepal-to-petal transformation was similarly observed with overexpression of the B function genes PISTILLATA (PI) [71, 72] in addition to GREEN PETAL in petunia [73]. Floral development phenotypes of tomato ap 2 mutants beyond SIAP $2 a$ 's role in ripening have not been reported to date. Thus, we cannot conclusively state that floral shift with overexpression of SlmiR172a in tomato result from repression of SIAP2 genes. Interestingly, tomato TAP3 and SlGLO1, B function genes shown to specify petal and stamen identities in their respective mutants, were also characterized by conversion of petals to sepal-like structures as well as conversion of stamens to carpel-like organs [74-76].

Previously reported activation-tagging showed miR172's involvement in Arabidopsis floral development and flowering-time control via post-transcriptional repression of two AP2-like genes, TOE1 and TOE2 [48, 50, 77, 78]. miR172 is influenced by GIGANTEA (GI) but not CONSTANS (CO) though CO is regulated by GI in addition to phytochromes (PHYs) and cryptochromes (CRYs). GI-mediated miR172 influences flowering time by regulating FLOWERING LOCUS $T(F T)$ and TOE1 [67, 79, 80]. Overexpression of SlmiR172a in tomato induced flowering 4-5 days earlier than WT or approximately one leaf earlier in phylotaxy (Fig. 3a, b). In transgenic tomato, the SFT (SINGLE FLOWER TRUSS) gene has been shown to induce flowering earlier than in the WT [81, 82], and the sft mutant delayed flowering time. Considering these data, we assumed that SlmiR172 and its target genes control the genetic pathway of flowering mediated by $S F T$ 
expression in photoperiod-insensitive tomato, as like photoperiodic Arabidopsis. Previously, we reported $S L A P 2 b$ and SlAP2c genes with a SlmiR172-specific perfect complementary binding site (Supplementary data 1), though no phenotypic changes with repression of SlAP2b and $S I A P 2 c$ either in the floral specification or flowering time were noted. As such, these phenotypes resulting from overexpression of SlmiR172a may reflect functional redundancy of targeted genes.

\section{Overexpression of SImiR172a phenocopies ripening effects of SIAP2a repression}

We predicted computationaly that miRNA172 targets the AP2 gene family. Previous studies in Arabidopsis, rose, and maize verified interaction of miR172 and AP2 family genes $[48-50,53,83,84]$. We previously demonstrated elevated SIAP2a transcript levels at the onset of fruit ripening, but not in flowers, and a role in ethylene regulation and ripening [42]. Like AP2 family genes in Arabidopsis and maize, SlAP2a also contains a miR172 binding site.

Ripening tomato fruits accumulate carotenoids, mainly lycopene and $\beta$-carotene, via gene expression-regulated metabolic flux influenced by the PSY1, PDS, ZDS, and $C Y C-B$ genes $[85,86]$. SlAP2a repression resulted in reduced lycopene and elevated $\beta$-carotene manifesting in orange fruit via reduced $P S Y 1$ and elevated $C Y C-B$ expression [42]. Fruit pigmentation in SlmiR172a OE lines was consistent with SlAP2a RNAi $[42,57,62,87]$ in that beta-carotene was substantially elevated. Indeed, SlmiR172a OE line \#13 had identical pigmentation to SIAP2a RNAi and the strongest transgenic expression line had greatest reduction in lycopene content (Figs. 5, 6, 7). When investigating the intensity of phenotypic traits influenced by miRNAs, miRNA accumulation has been shown to correlate with miRNA overexpression $[88,89]$.

We further demonstrated that SlmiR172a overexpression suppressed SlAP2a mRNA accumulation and SlmiR172a OE lines produced 3-4 times more ethylene during fruit ripening than WT consistent with increased expression of ethylene biosynthesis genes ACS2 and ACS4 (Figs. 8 and 9). This enhanced ethylene was identical to that observed in SlAP2a RNAi lines [42]. Fruit ripening time was 4-5 days earlier in SlmiR172a OE than WT, again similar to SlAP2a RNAi (Table 1). Ripeningacceleration in response to SlmiR172a OE has similarities to miR172 regulation of GLOSSY15 (GL15) in maize and Arabidopsis in that GL15 gene plays a primary role in maintaining juvenility while miR172 induction represses GL15 to promote developmental transitioning [51, 83, 90].

\section{Identification of miR172-guided cleavage of target mRNAs in tomato}

SlAP2 gene family members are miR172 targets in tomato $[55,58,91]$ though few of these interactions are functionally characterized beyond the APETALA2/ERF gene, SlAP2a [42]. Because most plant miRNAs are complementarity to their target genes, miRNA-mediated cleavage is likely the predominant mechanism of gene regulation [18, 20, 92, 93]. Interestingly, overexpression of miR172 in Arabidopsis down-regulated AP2 and AP2like $(T O E 1-2)$ by translation repression $[48-50,69]$ though substantial accumulation of target gene cleavage products was noted. In this case transcript levels were not reduced due to feed-back regulated induction via decreased AP2 protein.

Tomato miR172 has five predicted target genes including SlAP2a. We conducted 5'-RACE PCR for these genes and successfully identified cleavage sites in four, including SLAP2a. All identified cleavage events occurred near the middle of the complementary region and were identical to Arabidopsis miR172 cleavage sites (Fig. 10). There are at least three mature tomato isoforms of miR172. Using the modified RACE PCR we validated three target genes regulated by SlmiR172a and observed dramatically reduced $S l A P 2 a$ transcript levels in SlmiR172a OE lines (Supplementary Fig. S1A and additional file 1). These results are consistent with guided target gene cleavage as the predominant mechanism of SlmiR172 action, and support miR172 guided target gene cleavage [54]. However, reduced SIAP2a mRNA in SlmiR172a OE lines contrasts with observations in Arabidopsis $[39,48-50,60]$, suggesting that tomato miR172s regulate transcription largely by cleavage and may be less influenced by feedback regulation.

miR172 could be regulated by other transcription factors controlled by other miRNAs

SlmiRNA172a overexpression affected fruit ripening via $S L A P 2 a$. When we investigated the expression of key genes (MADS-RIN, CNR, HB1, and NOR) we found that mRNA levels were three times higher in the $C n r$ mutant than WT from the onset of ripening (30 days after $1 \mathrm{~cm}$ fruit) but not changed in the rin, nor or $\mathrm{Nr}$ mutants (Fig. 11 and additional file 1). SPL-CNR encodes an SBPbox (SQUAMOSA promoter binding protein-like, SPL) transcription factor, and the Cnr epimutation suppressed SlCNR expression and inhibited ripening [36, 94, 95]. $S l C N R$ is expressed in a fruit-specific manner and highest at the onset of ripening, tracking up-regulation of SlmiR172 in Cnr and suggesting SlmiR172 is negatively regulated by SPL-CNR during ripening and additional transcriptional inducers.

SPL7 is a member of the SPL family and binds the GTAC motif and regulates expression of miR398, miR397, miR408, and miR857, which are also induced under copper deficiency in Arabidopsis [96, 97]. Repression of Arabidopsis SPL3 regulated by miR156 causes transition from vegetative phase to floral induction. 
SlSPL-CNR is an ortholog of AtSPL3 (At2g33810) and contains the miR156 binding site in the $3^{\prime}$-UTR, implying that SlSPL-CNR could be regulated by SlmiR156 at ripening. The miR172 transcript is down-regulated by the dominant Congrass1 (Cg1) mutation and by overexpression of two tandem miR156 genes in maize, suggesting a converse regulatory relationship [98, 99].

\section{Conclusions}

Ripening of fleshy fruits like tomato is controlled by a complex regulatory network of multiple genes influenced by numerous internal and external cues. Previously, we reported the role of SIAP2a in the ripening process as a negative regulator of tomato fruit ripening modulating ethylene production and carotenoid pigmentation. We focused on identification of miRNAs targeted to SIAP2 genes regulating flowering and fruit ripening. We show that miR172 can repress SlAP2a transcript accumulation and enhance ripening by modulating ethylene and carotenoid pigmentation. Demonstration of miR172a-guided cleavage of SIAP2a transcripts provides a molecular mechanism for this aspect of ripening regulation and candidate genetic targets for modifying quality and nutritional value of fleshy fruit crops.

\section{Methods}

\section{Construction of miR172a OE vector and plant transformation}

A 403-bp fragment of predicted pre-miR172 sequence (Supplementary data 1) was amplified from BAC clone MboI0036L22-T7 by PCR with specific primers

(Fw 5'-GCGCGCTCTAGAGTATATATATGTAC TTGGATTTGTA-3',

Rev. 5'-GCGCGCGAGCTCGAACCCCAGTATAT ACAAAACCCT-3').

The fragment of $m i R 172 a$ precursor was gel-purified, cut by $X b a \mathrm{I}$ and $S a c \mathrm{I}$, and cloned into the transformation binary vector pBI121 under the control of the CaMV 35S promoter. The transformed plasmid vector was introduced into A. tumefaciens strain LBA4404 by electroporation and transformed into WT tomato cv. AC, as described [42].

\section{Plant material and treatments}

Transgenic and control plants were grown under standard greenhouse conditions at Cornell University (Ithaca, NY, USA). The greenhouse was equipped with heating, cooling, and supplemental lighting systems, and the plants were supplied with a slow-release fertilizer. We collected different types and stages of tissue: L (leaf), F (flower), D20 (20 days after $1 \mathrm{~cm}$ fruit), MG (mature green fruit), B (breaker fruit), B1 (1 day after breaker), B3 (3 days after breaker), B7 (7 days after breaker). On account that fruits of control and transgenic lines reached the breaker stage in different days after $1 \mathrm{~cm}$, MG-stage control and transgenic fruits were collected at 33 and 28 days after reaching $1 \mathrm{~cm}$, respectively. Time to ripening was measured by tagging $1-\mathrm{cm}$ ( $7-8$ days postanthesis) fruits and the number of days from $1 \mathrm{~cm}$ to Bstage was recorded. At least 25 fruit of each genotype were used for this experiment. Flowering time was counted by two different measurements (i) the number of days from sowing to full blooming flower, and (ii) the number of leaves produced below the first inflorescence.

\section{RNA isolation and gel-blot analysis}

Different developmental stages of tomato fruit were collected, immediately frozen in liquid nitrogen, and stored at $-80^{\circ} \mathrm{C}$. Total RNA was extracted from a pooled sample of five plants, 25 flowers and fruits for vegetative tissue and flower, as well as fruit samples at each developmental stage, respectively, as detailed in the literature [100]. For quantifying the total RNA, a NanoDrop ND-1000 spectrophotometer (Thermo Fisher Scientific, Waltham, MA, USA) was used.

For RNA blot analysis, $20 \mu \mathrm{g}$ of total RNA was fractionated on $1 \%(\mathrm{w} / \mathrm{v})$ agarose gel containing $7.5 \%(\mathrm{v} / \mathrm{v})$ formaldehyde and blotted onto Hybond $\mathrm{N}$ membrane (Amersham Biosciences, Piscataway, NJ, USA) following the method [42]. The membranes were incubated at $80^{\circ} \mathrm{C}$ for $2 \mathrm{~h}$ and then pre-hybridized for $3 \mathrm{~h}$, as per the membrane supplier's protocol, and hybridized at $65{ }^{\circ} \mathrm{C}$ to ${ }^{32} \mathrm{P}$-labeled random-primed DNA probes, synthesized as described previously [101]. Hybridizations were performed for at least $16 \mathrm{~h}$, and the filters were washed in 2X SSC containing $0.1 \%$ SDS (sodium dodecyl sulfate), and then $1 \mathrm{X}$ SSC containing $0.1 \%$ SDS at $65^{\circ} \mathrm{C}$. Signal intensity was visualized by autoradiography using Kodak X-OMAT-AR film (Sigma-Aldrich, St. Louis, MO, USA) with two intensifying screens at $-80{ }^{\circ} \mathrm{C}$.

For miRNA analysis, $50 \mu \mathrm{g}$ of total RNA was loaded on $20 \%$ polyacrylamide/7 M urea denaturing gels and blotted onto Hybond $\mathrm{N}$ membrane (Amersham Biosciences). Oligonucleotide antisense to miR172a was end-labeled with $\gamma-{ }^{32} \mathrm{P}$ using T4 polynucleotide kinase (New England Biolabs, Osaka, Japan) and hybridized to miRNA blots at $42{ }^{\circ} \mathrm{C}$ in hybridization buffer, which contained 5X SSC, 0.5\% SDS, $50 \mathrm{mM}$ potassium phosphate buffer ( $\mathrm{pH} 6.5$ ), and 5X Denhardt's solution [102]. The filters were washed twice in a mixture of $2 \mathrm{X} \mathrm{SSC}$ and $0.1 \%$ SDS at $42{ }^{\circ} \mathrm{C}$. Signal intensity was captured, as described above.

\section{Ethylene and carotenoid measurements}

Twenty-five fruit were harvested from each line at different ripening stages and pooled them for measuring the ethylene level and carotenoid content using a Hewlett-Packard HP 5890 series gas chromatograph equipped with a flame ionization detector, as detailed previously [103-106]. Fruits 
were harvested $3 \mathrm{~h}$ prior to measure ethylene and stored at room temperature for reducing harvest stress. Whole fruits were sealed in $250 \mathrm{ml}$ airtight jars and kept for $2 \mathrm{~h}$ at room temperate for measuring ethylene production, $1 \mathrm{ml}$ of headspace gas was taken from the chamber and injected into gas chromatograph (Hewlett- Packard 5890 series II; HewlettPackard, http://www.hp.com) equipped with flame ionization detector and activated alumina column. Ten (10) ppm ethylene was used as standard (Airgas, Inc., http:// www.airgas.com) for quantifying Ethylene concentrations, and normalized by fruit mass.

Carotenoid extraction and HPLC quantification were accomplished following the method described by [104-106]. Two hundred (200) mg frozen pericarp was homogenized with the mixture of $600 \mu \mathrm{l}$ tetrahydrofuran/methanol and $12.5 \mathrm{mg}$ of $\mathrm{MgCO}_{3} \cdot 2 \mathrm{H}_{2} \mathrm{O}$. The homogenate was filtered through spinning with a spin-X filter, then re-extracted by adding $550 \mu \mathrm{l}$ of tetrahydrofuran. One hundred fifty (150) $\mu \mathrm{l}$ of $25 \% \mathrm{NaCl}$ was added to partition the carotenoids into $325 \mu \mathrm{l}$ of petroleum ether. The extract was dried by evaporation. Dry extract was suspended into methyl t-butyl ether: methanol (500: 475), and filtrated through a syringe filter (GE Osmonics). A C30 reverse-phase column $(250 \times 4.6$ $\mathrm{mm}$ ) was used in HPLC and the separations were performed by using a summit HPLC system along with a PDA-100 photodiode array detector (Dionex Corporation, CA, USA). The elution gradients were run for $5 \mathrm{~min}$ to $100 \%$ methanol, 20 min to $95 \%$ t-butyl ether, 5 min to $95 \%$ t-butyl ether, and finally $5 \mathrm{~min}$ for returning the system to $100 \%$ methanol. Before each run the column was equilibrated for 10 min with $100 \%$ methanol. Purified standards and/or pigment-specific absorbance spectra was used for identifying the specific pigments.

\section{Modified 5' RNA ligase-mediated RACE for mapping of mRNA cleavage site}

RNA ligase-mediated rapid amplification of cDNA ends (5' RACE) was performed using Gene Racer Kit (Invitrogen, CA, USA) A with few modification [20]. Large-scale total RNA was extracted from different developmental stages of fruit and flower using a hot phenol method [107] and treated with RNAase-free DNAase (RNeasy Mini Kit, Qiagen Sciences, MD, USA). The total RNA concentration was quantified using ND-1000 v3.1.0 (NanoDrop Technologies, Wilmington, DE). Poly (A) ${ }^{+}$ mRNA was extracted by an Oligotex mRNA Midi Kit (Qiagen, CA, USA) from $500 \mu \mathrm{M}$ of total RNA.

Ligation of RNA adapter, reverse transcription, and 5 '-RACE PCR were carried out according to the manufacturer's instruction (Gene Racer Kit, Invitrogen) with $100 \mathrm{nM}$ poly $(\mathrm{A})^{+}$mRNA. Non-gene specific $5^{\prime}$-RACE products were generated by amplification with the Gene Racer 5' Primer (5'-CGACTGGAGCACGAGGAC ACTGA-3') and Gene Racer 3' Primer (5'-GCTGTC
AACGATACGCTACGTAACG-3'). Gene-specific 5' RACE reactions were conducted with the Gene Racer 5' Nested Primer and gene-specific primers as follows: PCR products were gel-purified, cloned into a plasmid vector using the TA TOPO PCR Cloning Kit (Invitrogen), and sequenced using the Illumina platform.

\section{Semi-quantitative RT-PCR analysis}

For RT-PCR analysis, first-strand cDNA was synthesized from $3 \mu \mathrm{g}$ of total RNA using superscript III reverse transcriptase (Invitrogen) and oligo-dT primer according to the manufacturer's protocol. PCR was conducted using SlAP2b-specific primers (Supplementary Table S1) following 1 cycle at $94^{\circ} \mathrm{C}$ for $3 \mathrm{~min} ; 30$ cycles at $94^{\circ} \mathrm{C}$ for $1 \mathrm{~min}, 50^{\circ} \mathrm{C}$ for $2 \mathrm{~min}$, and $72^{\circ} \mathrm{C}$ for $10 \mathrm{~min}$; where firststrand cDNA was used as a template.

\section{Supplementary information}

Supplementary information accompanies this paper at https://doi.org/10. 1186/s12870-020-02489-y.

\begin{abstract}
Additional file 1 : Supplementary Table S1. List of specific primers used in RT-PCR

Additional file 2 : Supplementary Fig. S1. RACE-PCR analysis of miR172 cleaved products. Analysis was performed on wild-type and miR172 OE lines for (A) ripening stage fruit (B3) and (B) flowers. A fragment of the EF1-a gene was amplified in the same PCR reaction as an internal control. Supplementary Fig. S2. Expression level of the SIAP2a gene in wild-type and miR172 OE lines. WT and miR172 OE lines \#16 and \#26 tissues ( $L$, leaf; B, breaker; B3, 3 days after breaker) were analyzed. The same filter was stripped and rehybridized to tomato a18S rRNA probe as a loading control. Supplementary Fig. S3. miR172 transcript abundance in wild-type (WT) and ripening mutants (rin, nor, Nr, Cnr). Tomato tissues (L, leaf; F, flower; D10, 10 days after $1 \mathrm{~cm}$ fruit; D20, 20 days after $1 \mathrm{~cm}$ fruit; D30, 30 days after $1 \mathrm{~cm}$ fruit; D35, 35 days after $1 \mathrm{~cm}$ fruit), were harvested, extracted for total RNA and $50 \mu \mathrm{g}$ was loaded for RNA gel-blot analysis using a 5'-end-labeled DNA oligonucleotide probe complementary to miR172. 5S rRNA was used as a loading control. Supplementary Fig. S4. Accumulation of miR172 in wild-type and Cnr mutant fruit. Tomato tissues (F, flower; D10, 10 days after $1 \mathrm{~cm}$ fruit; D20, 20 days after 1 $\mathrm{cm}$ fruit; D30, 30 days after $1 \mathrm{~cm}$ fruit; D35, 35 days after $1 \mathrm{~cm}$ fruit) were extracted for total RNA of which $20 \mu \mathrm{g} / \mathrm{sample}$ was separated for RNA gel-blot analysis using a 5'-end-labeled DNA oligonucleotide complementary to miR172 as probe. Tomato 5S rRNA was used as a loading control. RNA gel-blot analysis was repeated three times and relative expression was determined relative to transcript levels in flower.
\end{abstract}

Additional file 3 : Supplementary data 1. Sequences of $A P 2$ family genes and putative miR172 binding sites

Additional file 4. : Additional file 1. Gel images of Northern blot and RACE-PCR electrophoresis performed for different genes and RNAs which are used in this manuscript.

\section{Abbreviations}

ACO1: 1-AMINOCYCLOPROPANE-1-CARBOXYLIC ACID OXIDASE;" ACS2: 1AMINOCYCLOPROPANE 1-CARBOXYLIC ACID SYNTHASE; AP2: APETALA2; B: Breaker fruit; B1: 1 day after breaker; B3: 3 days after breaker; B7: 7 days after breaker; BAC: Bacterial Artificial Chromosome; Cnr: Colorless non-ripening; CO: CONSTANS; CRY: Cryptochromes; CYC-B: Lycopene- $\beta$-cyclase; D20: 20 days after $1 \mathrm{~cm}$ fruit; DCL: Dicer-like; DXS1: 1-deoxy-D-xylulose 5-phosphate synthase; F: Flower; FT: FLOWERING LOCUS T; gf: green flesh; GI: GIGANTEA; gl15: glossy15; Gr: Green-ripe; HB1: HD-ZIP HOMEOBOX PROTEIN-1; HPLC: High performance liquid chromatography; L: Leaf; RIN: RIPENING INHIBITOR; MG: Mature green fruit; miRNA: MicroRNA; ND: NanoDrop; NOR: NON-RIPENING; Nr: Never-ripe; 
OE: Overexpression; PDA: Potato Dextrose Agar; PDS: Phytoene desaturase; PHYs: Phytochromes; PI: PISTILLATA; pri-miRNA: primary transcript RNA; PSY1: Phytoene synthase 1; RISC: RNA-induced silencing complex; RNA: Ribo Nucleic Acid; SFT: SINGLE FLOWER TRUSS; TOE1: TARGET OF EAT1; TOE2: TARGET OF EAT2; WT: Wild; ZDS: ל-carotene desaturase

\section{Acknowledgments}

We thank all the colleagues in our laboratory for providing useful discussions and technical assistance. We are very grateful to the editor and reviewers for critically evaluating the manuscript and providing constructive comments for its improvement.

\section{Authors' contributions}

MYC performed the experiment and analyzed data. UKN wrote the manuscript. JV, NG, JML, and DJL analyzed the data and revised the manuscript. JG and CKK planned, executed and monitored the experiment, and critically revised the manuscript. All authors read and approved the final manuscript.

\section{Funding}

This work was supported by the National Research Foundation of Korea (NRF) grant funded by the Korea government (MSIT) (No. NRF2018R1A2B6001781) and National Science Foundation Grant IOS-1339287.

\section{Availability of data and materials}

The datasets used and/or analysed during the current study available from the corresponding author on reasonable request.

\section{Ethics approval and consent to participate}

Plant materials and germplasm used in the analysis are maintained in accordance with the institutional guidelines of the Boyce Thompson Institute for Plant Research, Cornell University, USA. This article did not contain any studies with human participants or animals and did not involve any endangered or protected species.

\section{Consent for publication}

Not applicable.

\section{Competing interests}

The authors declared no competing interests.

\section{Author details}

${ }^{1}$ Department of Agricultural Education, Sunchon National University, Suncheon, South Korea. ${ }^{2}$ Department of Genetics and Plant Breeding, Bangladesh Agricultural University, Mymensingh 2202, Bangladesh. ${ }^{3}$ Boyce Thompson Institute for Plant Research, Cornell University, Ithaca, New York, USA. ${ }^{4}$ Department of Horticulture, Kyungpook National University, Daegu, Korea. ${ }^{5}$ US Department of Agriculture/Agriculture Research Service, Robert W. Holley Centre for Agriculture and Health, Ithaca, New York, USA.

\section{Received: 15 December 2019 Accepted: 11 June 2020}

Published online: 19 June 2020

\section{References}

1. Fang $Y$, Spector DL. Identification of nuclear dicing bodies containing proteins for microRNA biogenesis in living Arabidopsis plants. Curr Biol. 2007;17(9):818-23.

2. Dong $\mathrm{Z}, \mathrm{Han} \mathrm{M}-\mathrm{H}$, Fedoroff $\mathrm{N}$. The RNA-binding proteins HYL1 and SE promote accurate in vitro processing of pri-miRNA by DCL1. Proc Natl Acad Sci. 2008;105(29):9970-5.

3. Axtell MJ, Meyers BC. Revisiting criteria for plant microRNA annotation in the era of big data. Plant Cell. 2018;30(2):272-84.

4. Budak H, Akpinar BA. Plant miRNAs: biogenesis, organization and origins. Funct Integr Genomics. 2015;15(5):523-31.

5. Rhoades MW, Reinhart BJ, Lim LP, Burge CB, Bartel B, Bartel DP. Prediction of plant microRNA targets. cell. 2002;110(4):513-20.

6. Jones-Rhoades MW, Bartel DP, Bartel B. MicroRNAs and their regulatory roles in plants. Annu Rev Plant Biol. 2006;57:19-53.

7. Ballester A-R, Molthoff J, de Vos R, te Lintel HB, Orzaez D, FernándezMoreno J-P, Tripodi P, Grandillo S, Martin C, Heldens J. Biochemical and molecular analysis of pink tomatoes: deregulated expression of the gene encoding transcription factor SIMYB12 leads to pink tomato fruit color. Plant Physiol. 2010;152(1):71-84.

8. Matzke M, Kanno T, Daxinger L, Huettel B, Matzke AJ. RNA-mediated chromatin-based silencing in plants. Curr Opin Cell Biol. 2009;21(3):367-76.

9. Bartel DP. Metazoan micrornas. Cell. 2018;173(1):20-51.

10. Borges F, Martienssen RA. The expanding world of small RNAs in plants. Nat Rev Mol Cell Biol. 2015;16(12):727.

11. Krol J, Loedige I, Filipowicz W. The widespread regulation of microRNA biogenesis, function and decay. Nat Rev Genet. 2010;11(9):597.

12. Zhang $B$, Wang $Q$, Pan X. MicroRNAs and their regulatory roles in animals and plants. J Cell Physiol. 2007;210(2):279-89.

13. Gurtan AM, Sharp PA. The role of miRNAs in regulating gene expression networks. J Mol Biol. 2013;425(19):3582-600.

14. Catalanotto C, Cogoni C, Zardo G. MicroRNA in control of gene expression: an overview of nuclear functions. Int J Mol Sci. 2016;17(10):1712.

15. Song X, Li Y, Cao X, Qi Y. MicroRNAs and their regulatory roles in plantenvironment interactions. Annu Rev Plant Biol. 2019;70:489-525.

16. Wang $Y$, Juranek S, Li H, Sheng G, Wardle GS, Tuschl T, Patel DJ. Nucleation, propagation and cleavage of target RNAs in ago silencing complexes. Nature. 2009;461(7265):754.

17. Voinnet O. Origin, biogenesis, and activity of plant microRNAs. Cell. 2009; 136(4):669-87.

18. Llave C, Kasschau KD, Rector MA, Carrington JC. Endogenous and silencingassociated small RNAs in plants. Plant Cell. 2002;14(7):1605-19.

19. Kasschau KD, Xie Z, Allen E, Llave C, Chapman EJ, Krizan KA, Carrington JC P1/HC-Pro, a viral suppressor of RNA silencing, interferes with Arabidopsis development and miRNA function. Dev Cell. 2003:4(2):205-17.

20. Jones-Rhoades MW, Bartel DP. Computational identification of plant microRNAs and their targets, including a stress-induced miRNA. Mol Cell. 2004;14(6):787-99.

21. Park JH, Shin C. MicroRNA-directed cleavage of targets: mechanism and experimental approaches. BMB Rep. 2014;47(8):417.

22. D'Ario M, Griffiths-Jones S, Kim M. Small RNAs: big impact on plant development. Trends Plant Sci. 2017;22(12):1056-68.

23. Sanan-Mishra N, Kumar V, Sopory SK, Mukherjee SK. Cloning and validation of novel miRNA from basmati rice indicates cross talk between abiotic and biotic stresses. Mol Gen Genomics. 2009;282(5):463.

24. Bej S, Basak J. MicroRNAs: the potential biomarkers in plant stress response. Am J Plant Sci. 2014;5(05):748.

25. Djami-Tchatchou AT, Dubery IA. Lipopolysaccharide perception leads to dynamic alterations in the microtranscriptome of Arabidopsis thaliana cells and leaf tissues. BMC Plant Biol. 2015;15(1):79.

26. Sun G. MicroRNAs and their diverse functions in plants. Plant Mol Biol. 2012; 80(1):17-36

27. Xie F, Stewart CN Jr, Taki FA, He Q, Liu H, Zhang B. High-throughput deep sequencing shows that micro RNAs play important roles in switchgrass responses to drought and salinity stress. Plant Biotechnol J. 2014;12(3):354-66.

28. Zhang Y, Wang W, Chen J, Liu J, Xia M, Shen F. Identification of miRNAs and their targets in cotton inoculated with Verticillium dahliae by highthroughput sequencing and degradome analysis. Int J Mol Sci. 2015;16(7): 14749-68.

29. Klee HJ, Giovannoni JJ. Genetics and control of tomato fruit ripening and quality attributes. Annu Rev Genet. 2011;45:41-59.

30. Consortium TG. The tomato genome sequence provides insights into fleshy fruit evolution. Nature. 2012;485(7400):635.

31. Giovannoni J, Nguyen C, Ampofo B, Zhong S, Fei Z. The epigenome and transcriptional dynamics of fruit ripening. Annu Rev Plant Biol. 2017;68:61-84.

32. Shinozaki Y, Nicolas P, Fernandez-Pozo N, Ma Q, Evanich DJ, Shi Y, Xu Y, Zheng $Y$, Snyder SI, Martin LB. High-resolution spatiotemporal transcriptome mapping of tomato fruit development and ripening. Nat Commun. 2018;9(1):364.

33. Gao L, Gonda I, Sun H, Ma Q, Bao K, Tieman DM, Burzynski-Chang EA, Fish $\mathrm{TL}$, Stromberg KA, Sacks GL. The tomato pan-genome uncovers new genes and a rare allele regulating fruit flavor. Nat Genet. 2019;51(6):1044.

34. Giovannoni JJ. Fruit ripening mutants yield insights into ripening control. Curr Opin Plant Biol. 2007;10(3):283-9.

35. Vrebalov J, Ruezinsky D, Padmanabhan V, White R, Medrano D, Drake R, Schuch W, Giovannoni J. A MADS-box gene necessary for fruit ripening at the tomato ripening-inhibitor (rin) locus. Science. 2002;296(5566):343-6.

36. Manning K, Tör M, Poole M, Hong Y, Thompson AJ, King GJ, Giovannoni JJ, Seymour GB. A naturally occurring epigenetic mutation in a gene encoding 
an SBP-box transcription factor inhibits tomato fruit ripening. Nat Genet. 2006:38(8):948.

37. Barry CS, McQuinn RP, Chung M-Y, Besuden A, Giovannoni JJ. Amino acid substitutions in homologs of the STAY-GREEN protein are responsible for the green-flesh and chlorophyll retainer mutations of tomato and pepper. Plant Physiol. 2008;147(1):179-87.

38. Ma N, Feng H, Meng X, Li D, Yang D, Wu C, Meng Q. Overexpression of tomato SINAC1 transcription factor alters fruit pigmentation and softening. BMC Plant Biol. 2014;14(1):351.

39. Wang R, da Rocha Tavano EC, Lammers M, Martinelli AP, Angenent GC, de Maagd RA. Re-evaluation of transcription factor function in tomato fruit development and ripening with CRISPR/Cas9-mutagenesis. Sci Rep. 2019;9(1):1696.

40. Dong T, Hu Z, Deng L, Wang Y, Zhu M, Zhang J, Chen G. A tomato MADSbox transcription factor, SIMADS1, acts as a negative regulator of fruit ripening. Plant Physiol. 2013;163(2):1026-36.

41. Zhao X, Yuan X, Chen S, Meng L, Fu D. Role of the tomato TAGL1 gene in regulating fruit metabolites elucidated using RNA sequence and metabolomics analyses. PLoS One. 2018;13(6):e0199083.

42. Chung MY, Vrebalov J, Alba R, Lee J, McQuinn R, Chung JD, Klein P, Giovannoni J. A tomato (Solanum lycopersicum) APETALA2/ERF gene, SIAP2a, is a negative regulator of fruit ripening. Plant J. 2010;64(6):936-47.

43. Bemer M, Karlova R, Ballester AR, Tikunov YM, Bovy AG, Wolters-Arts M, de Barros RP, Angenent GC, de Maagd RA. The tomato FRUITFULL homologs TDR4/FUL1 and MBP7/FUL2 regulate ethylene-independent aspects of fruit ripening. Plant Cell. 2012;24(11):4437-51.

44. Vrebalov J, Pan IL, Arroyo AJM, McQuinn R, Chung M, Poole M, Rose J, Seymour G, Grandillo S, Giovannoni J. Fleshy fruit expansion and ripening are regulated by the tomato SHATTERPROOF gene TAGL1. Plant Cell. 2009; 21(10):3041-62.

45. Gao C, Ju Z, Cao D, Zhai B, Qin G, Zhu H, Fu D, Luo Y, Zhu B. Micro RNA profiling analysis throughout tomato fruit development and ripening reveals potential regulatory role of RIN on micro RNA $s$ accumulation. Plant Biotechnol J. 2015;13(3):370-82.

46. Wu L, Zhou H, Zhang Q, Zhang J, Ni F, Liu C, Qi Y. DNA methylation mediated by a microRNA pathway. Mol Cell. 2010;38(3):465-75.

47. Yan Z, Hossain MS, Wang J, Valdés-López O, Liang Y, Libault M, Qiu L, Stacey G. miR172 regulates soybean nodulation. Mol Plant-Microbe Interact. 2013;26(12):1371-7.

48. Zhu Q-H, Helliwell CA. Regulation of flowering time and floral patterning by miR172. J Exp Bot. 2010;62(2):487-95.

49. Chen X. A microRNA as a translational repressor of APETALA2 in Arabidopsis flower development. Science. 2004;303(5666):2022-5

50. Aukerman MJ, Sakai $H$. Regulation of flowering time and floral organ identity by a microRNA and its APETALA2-like target genes. Plant Cell. 2003; 15(11):2730-41.

51. Lauter N, Kampani A, Carlson S, Goebel M, Moose SP. microRNA172 downregulates glossy15 to promote vegetative phase change in maize. Proc Natl Acad Sci. 2005;102(26):9412-7.

52. Wu G, Poethig RS. Temporal regulation of shoot development in Arabidopsis thaliana by miR156 and its target SPL3. Development. 2006;133(18):3539-47.

53. Chuck G, Meeley R, Irish E, Sakai H, Hake S. The maize tasselseed4 microRNA controls sex determination and meristem cell fate by targeting Tasselseed6/ indeterminate spikelet1. Nat Genet. 2007:39(12):1517.

54. Schwab R, Palatnik JF, Riester M, Schommer C, Schmid M, Weigel D. Specific effects of microRNAs on the plant transcriptome. Dev Cell. 2005;8(4):517-27.

55. Yin Z, Li C, Han X, Shen F. Identification of conserved microRNAs and their target genes in tomato (Lycopersicon esculentum). Gene. 2008;414(1-2):60-6.

56. Jung J-H, Lee S, Yun J, Lee M, Park C-M. The miR172 target TOE3 represses AGAMOUS expression during Arabidopsis floral patterning. Plant Sci. 2014; 215:29-38.

57. Karlova R, Rosin FM, Busscher-Lange J, Parapunova V, Do PT, Fernie AR, Fraser PD, Baxter C, Angenent GC, de Maagd RA. Transcriptome and metabolite profiling show that APETALA2a is a major regulator of tomato fruit ripening. Plant Cell. 2011:23(3):923-41.

58. Zhang J, Zeng R, Chen J, Liu X, Liao Q. Identification of conserved microRNAs and their targets from Solanum lycopersicum mill. Gene. 2008; 423(1):1-7.

59. Luo Y, Guo Z, Li L. Evolutionary conservation of microRNA regulatory programs in plant flower development. Dev Biol. 2013;380(2):133-44.

60. Wang $T$, Ping $X$, Cao $Y$, Jian H, Gao Y, Wang J, Tan Y, Xu X, Lu K, Li J. Genome-wide exploration and characterization of miR172/euAP2 genes in
Brassica napus L. for likely role in flower organ development. BMC Plant Biol. 2019;19(1):336.

61. Itaya A, Bundschuh R, Archual AJ, Joung J-G, Fei Z, Dai X, Zhao PX, Tang Y, Nelson RS, Ding B. Small RNAs in tomato fruit and leaf development. Biochim Biophys Acta. 2008;1779(2):99-107.

62. Karlova $R$, van Haarst JC, Maliepaard C, van de Geest H, Bovy AG, Lammers $M$, Angenent GC, de Maagd RA. Identification of microRNA targets in tomato fruit development using high-throughput sequencing and degradome analysis. J Exp Bot. 2013;64(7):1863-78.

63. Aguilar-Jaramillo AE, Marín-González E, Matías-Hernández L, Osnato M, Pelaz S, Suárez-López P. TEMPRANILLO is a direct repressor of the micro RNA miR172. Plant J. 2019;100(3):522-53.

64. Fernandez-Pozo N, Menda N, Edwards JD, Saha S, Tecle IY, Strickler SR, Bombarely A, Fisher-York T, Pujar A, HJNar F. The Sol Genomics Network (SGN)_from genotype to phenotype to breeding. Nucleic Acids Res. 2015;43(D1):D1036-41.

65. Coen ES, Meyerowitz EM. The war of the whorls: genetic interactions controlling flower development. Nature. 1991;353(6339):31.

66. Irish V. The ABC model of floral development. Curr Biol. 2017;27(17):R887-

67. Jung J-H, Seo Y-H, Seo PJ, Reyes JL, Yun J, Chua N-H, Park C-M. The GIGANTEA-regulated microRNA172 mediates photoperiodic flowering independent of CONSTANS in Arabidopsis. Plant Cell. 2007;19(9):2736-48.

68. Wollmann $\mathrm{H}$, Mica E, Todesco M, Long JA, Weigel D. On reconciling the interactions between APETALA2, miR172 and AGAMOUS with the ABC model of flower development. Development. 2010;137(21):3633-42.

69. Wang P, Cheng T, Lu M, Liu G, Li M, Shi J, Lu Y, Laux T, Chen J. Expansion and functional divergence of AP2 group genes in spermatophytes determined by molecular evolution and Arabidopsis mutant analysis. Front Plant Sci. 2016;7:1383.

70. Krogan NT, Hogan K, Long JA. APETALA2 negatively regulates multiple floral organ identity genes in Arabidopsis by recruiting the co-repressor TOPLESS and the histone deacetylase HDA19. Development. 2012;139(22):4180-90.

71. Krizek BA, Meyerowitz EM. The Arabidopsis homeotic genes APETALA3 and PISTILLATA are sufficient to provide the B class organ identity function. Development. 1996;122(1):11-22.

72. Tzeng T-Y, Kong L-R, Chen $\mathrm{C}-\mathrm{H}$, Shaw $\mathrm{C}-\mathrm{C}$, Yang $\mathrm{C}-\mathrm{H}$. Overexpression of the lily p70s6k gene in Arabidopsis affects elongation of flower organs and indicates TOR-dependent regulation of AP3, PI and SUP translation. Plant Cell Physiol. 2009;50(9):1695-709.

73. Rijpkema AS, Royaert S, Zethof J, van der Weerden G, Gerats T, Vandenbussche M. Analysis of the Petunia TM6 MADS box gene reveals functional divergence within the DEF/AP3 lineage. Plant Cell. 2006;18(8):1819-32.

74. De Martino G, Pan I, Emmanuel E, Levy A, Irish VF. Functional analyses of two tomato APETALA3 genes demonstrate diversification in their roles in regulating floral development. Plant Cell. 2006;18(8):1833-45.

75. Quinet M, Bataille G, Dobrev PI, Capel C, Gómez P, Capel J, Lutts S, Motyka $V$, Angosto T, Lozano R. Transcriptional and hormonal regulation of petal and stamen development by STAMENLESS, the tomato (Solanum lycopersicum L.) orthologue to the B-class APETALA3 gene. J Exp Bot. 2014; 65(9):2243-56

76. Guo X, Hu Z, Yin W, Yu X, Zhu Z, Zhang J, Chen G. The tomato floral homeotic protein FBP1-like gene, SIGLO1, plays key roles in petal and stamen development. Sci Rep. 2016:6:20454.

77. Mathieu J, Yant LJ, Mürdter F, Küttner F, Schmid M. Repression of flowering by the miR172 target SMZ. PLoS Biol. 2009;7(7):e1000148.

78. Spanudakis $\mathrm{E}$, Jackson $\mathrm{S}$. The role of microRNAs in the control of flowering time. J Exp Bot. 2014;65(2):365-80.

79. Srikanth A, Schmid M. Regulation of flowering time: all roads lead to Rome. Cell Mol Life Sci. 2011;68(12):2013-37.

80. Matsoukas IG, Massiah AJ, Thomas B. Florigenic and antiflorigenic signaling in plants. Plant Cell Physiol. 2012;53(11):1827-42

81. Cao K, Cui L, Zhou X, Ye L, Zou Z, Deng S. Four tomato FLOWERING LOCUS T-like proteins act antagonistically to regulate floral initiation. Front Plant Sci. 2016;6:1213.

82. Lifschitz E, Eviatar T, Rozman A, Shalit A, Goldshmidt A, Amsellem Z, Alvarez $J P$, Eshed $Y$. The tomato FT ortholog triggers systemic signals that regulate growth and flowering and substitute for diverse environmental stimuli. Proc Natl Acad Sci. 2006;103(16):6398-403.

83. Wu G, Park MY, Conway SR, Wang J-W, Weigel D, Poethig RS. The sequential action of miR156 and miR172 regulates developmental timing in Arabidopsis. cell. 2009;138(4):750-9. 
84. François $L$, Verdenaud M, Fu X, Ruleman D, Dubois A, Vandenbussche M, Bendahmane A, Raymond O, Just J, Bendahmane M. A miR172 targetdeficient AP2-like gene correlates with the double flower phenotype in roses. Sci Rep. 2018;8(1):12912.

85. Burns J, Fraser PD, Bramley PM. Identification and quantification of carotenoids, tocopherols and chlorophylls in commonly consumed fruits and vegetables. Phytochemistry. 2003;62(6):939-47.

86. Ronen G, Carmel-Goren L, Zamir D, Hirschberg J. An alternative pathway to $\beta$-carotene formation in plant chromoplasts discovered by map-based cloning of Beta and old-gold color mutations in tomato. Proc Natl Acad Sci. 2000:97(20):11102-7.

87. Stanley L, Yuan Y-W. Transcriptional regulation of carotenoid biosynthesis in plants: so many regulators, so little consensus. Front Plant Sci. 2019;10:1017.

88. Djami-Tchatchou AT, Sanan-Mishra N, Ntushelo K, Dubery IA. Functional roles of microRNAs in agronomically important plants-potential as targets for crop improvement and protection. Front Plant Sci. 2017:8:378.

89. Laufs $P$, Peaucelle A, Morin $H$, Traas J. MicroRNA regulation of the CUC genes is required for boundary size control in Arabidopsis meristems. Development. 2004;131(17):4311-22.

90. Xu D, Wang X, Huang C, Xu G, Liang Y, Chen Q, Wang C, Li D, Tian J, Wu L. Glossy 15 plays an important role in the divergence of the vegetative transition between maize and its progenitor, teosinte. Mol Plant. 2017;10(12):1579-83.

91. de Sousa Cardoso TC, Alves TC, Caneschi CM, DdRG S, Fernandes-Brum CN, dos Reis GL, Daude MM, THC R, MMD G, Lima AA. New insights into tomato microRNAs. Sci Rep. 2018;8(1):16069.

92. Mallory AC, Vaucheret $\mathrm{H}$. Functions of microRNAs and related small RNAs in plants. Nat Genet. 2006;38(6s):S31.

93. Wang J, Mei J, Ren G. Plant microRNAs: biogenesis, homeostasis and degradation. Front Plant Sci. 2019;10:360.

94. Chen W, Kong J, Lai T, Manning K, Wu C, Wang Y, Qin C, Li B, Yu Z, Zhang $X$. Tuning LeSPL-CNR expression by SlymiR157 affects tomato fruit ripening. Sci Rep. 2015;5:7852.

95. Ecker JR. Epigenetic trigger for tomato ripening. Nat Biotechnol. 2013;31(2):119.

96. Preston JC, Hileman L. Functional evolution in the plant SQUAMOSA-PROMOTER BINDING PROTEIN-LIKE (SPL) gene family. Front Plant Sci. 2013;4:80.

97. Burkhead JL, Gogolin Reynolds KA, Abdel-Ghany SE, Cohu CM, Pilon M. Copper homeostasis. New Phytol. 2009;182(4):799-816.

98. Chuck G, Cigan AM, Saeteurn K, Hake S. The heterochronic maize mutant Corngrass 1 results from overexpression of a tandem microRNA. Nat Genet. 2007;39(4):544

99. Wang $H$, Wang $H$. The miR156/SPL module, a regulatory hub and versatile toolbox, gears up crops for enhanced agronomic traits. Mol Plant. 2015;8(5): 677-88.

100. Chang S, Puryear J, Cairney J. A simple and efficient method for isolating RNA from pine trees. Plant Mol Biol Report. 1993;11(2):113-6.

101. Feinberg AP, Vogelstein B. A technique for radiolabeling DNA restriction endonuclease fragments to high specific activity. Anal Biochem. 1983; 132(1):6-13.

102. Barry CS, McQuinn RP, Thompson AJ, Seymour GB, Grierson D, Giovannoni JJ. Ethylene insensitivity conferred by the Green-ripe and Never-ripe 2 ripening mutants of tomato. Plant Physiol. 2005;138(1):267-75.

103. Cristescu SM, Mandon J, Arslanov D, De Pessemier J, Hermans C, Harren FJ. Current methods for detecting ethylene in plants. Ann Bot. 2012 111(3):347-60.

104. Alba R, Payton P, Fei Z, McQuinn R, Debbie P, Martin GB, Tanksley SD, Giovannoni JJ. Transcriptome and selected metabolite analyses reveal multiple points of ethylene control during tomato fruit development. Plant Cell. 2005;17(11):2954-65.

105. Fraser PD, Pinto MES, Holloway DE, Bramley PM. Application of highperformance liquid chromatography with photodiode array detection to the metabolic profiling of plant isoprenoids. Plant J. 2000;24(4):551-8.

106. Richins RD, Kilcrease J, Rodgriguez-Uribe L, O'Connell MA. Carotenoid extraction and quantification from Capsicum annuum. Bio Protoc. 2014; 4(19):e1256

107. Wasniewski J. RNA extraction protocol development for the assay of temporal gene expression in batch-cultured Escherichia coli K-12. Ontario: McMaster University; 2012.

\section{Publisher's Note}

Springer Nature remains neutral with regard to jurisdictional claims in published maps and institutional affiliations.

\section{Ready to submit your research? Choose BMC and benefit from}

- fast, convenient online submission

- thorough peer review by experienced researchers in your field

- rapid publication on acceptance

- support for research data, including large and complex data types

- gold Open Access which fosters wider collaboration and increased citations

- maximum visibility for your research: over $100 \mathrm{M}$ website views per year

At BMC, research is always in progress.

Learn more biomedcentral.com/submissions 